\title{
A Noteworthy New Species of Peritassa (Celastraceae, Hippocrateoideae) from Amazonian Brazil
}

Author(s): Julio Antonio Lombardi

Source: Novon: A Journal for Botanical Nomenclature, 17(1):29-32. 2007.

Published By: Missouri Botanical Garden

DOI: http://dx.doi.org/10.3417/1055-3177(2007)17[29:ANNSOP]2.0.CO;2

URL: http://www.bioone.org/doi/

full/10.3417/1055-3177\%282007\%2917\%5B29\%3AANNSOP\%5D2.0.CO

$\% 3 \mathrm{~B} 2$

BioOne (www.bioone.org) is a nonprofit, online aggregation of core research in the biological, ecological, and environmental sciences. BioOne provides a sustainable online platform for over 170 journals and books published by nonprofit societies, associations, museums, institutions, and presses.

Your use of this PDF, the BioOne Web site, and all posted and associated content indicates your acceptance of BioOne's Terms of Use, available at www.bioone.org/ page/terms of use.

Usage of BioOne content is strictly limited to personal, educational, and noncommercial use. Commercial inquiries or rights and permissions requests should be directed to the individual publisher as copyright holder. 


\title{
A Noteworthy New Species of Peritassa (Celastraceae, Hippocrateoideae) from Amazonian Brazil
}

\author{
Julio Antonio Lombardi \\ Departamento de Botânica, Instituto de Biociências, Universidade Estadual Paulista 'Júlio de \\ Mesquita Filho', Av. 24-A 1515, 13506-900, Rio Claro, São Paulo, Brazil. cissus@rc.unesp.br
}

Abstract. The new species Peritassa manaoara Lombardi differs from other species in Peritassa Miers by its unique 3 -lobed stigma. The inclusion of this new taxon in Peritassa was based on the characteristics of non-confluent anther locules and the disc free from the ovary wall, which distinguishes this species from Tontelea Aublet, the only other genus of Neotropical Hippocrateoideae species with a 3-lobed stigma and tubular nectariferous disc.

Resumo. A nova espécie Peritassa manaoara Lombardi é distinta de todas as outras espécies de Peritassa Miers pelo seu estigma trilobado único. A inclusão deste taxon novo em Peritassa foi baseada na característica das anteras com lóculos não confluentes e disco nectarífero livre da parede do ovário, isso coloca essa espécie aparte daquelas incluídas em Tontelea Aublet, o único outro gênero Neotropical de Hippocrateoideae com espécies com estigma trilobado e disco tubular.

Key words: Amazon basin, Brazil, Celastraceae, Hippocrateoideae, IUCN Red List, Peritassa.

The Hippocrateaceae are now included in Celastraceae as the subfamily Hippocrateoideae, a taxon including five tribes, 24 genera, and ca. 357 described species (Hallé, 1990; Mennega, 1997) distributed worldwide in tropical and subtropical areas.

The delimitations of Neotropical genera in the Hippocrateaceae are notoriously controversial and range from two, Salacia L. and Hippocratea L. (Peyritsch, 1878), to 17, according to Miers (1872). In this work, I follow Smith (1940), who recognizes three genera segregated from Salacia, Cheiloclinium Miers, Peritassa Miers, and Tontelea Aublet and included in the tribe Salacieae with the African Salacighia Loesener and Thyrsosalacia Loesener (Mennega, 1997).

The genus Peritassa, with 17 described species (Lombardi, 2004; Lombardi \& Temponi, 1999; Mennega, 1997) is exclusively Neotropical. It was described by Miers (1872) and segregated from Salacia because of the presence of anthers with a longitudinal dehiscence and a prominent connective, and of a tubular nectariferous disc. Other species with no prominent connective and different dehiscence were added later (Lombardi, 2004; Lombardi \& Temponi, 1999; Smith, 1940).

These species have inconspicuous anther connectives and oblique dehiscence clefts, almost transverse, and are distinguished from other fleshy-fruited genera (tribe Salacieae, Mennega, 1997) by their anther locules not confluent at the apex, although dehiscent by oblique clefts (Smith, 1940: 501).

While working on a taxonomic study of the Brazilian species of Hippocrateoideae as part of a study of the Neotropical species, I discovered a noteworthy new species from the rainforests around Manaus, in the Brazilian Amazon basin.

Peritassa manaoara Lombardi, sp. nov. TYPE: Brazil. Amazonas: Reserva Flor. Ducke, Manaus-Itacoatiara, $\mathrm{km} \mathrm{26,} 02^{\circ} 53^{\prime} \mathrm{S}, \quad 59^{\circ} 58^{\prime} \mathrm{W}$, Igarapé do Tinga, Floresta de Campinarana, 7 Dec. 1994, A. Vicentini 789 \& E. C. Pereira (holotype, IAN; isotypes, G not seen, INPA not seen, K not seen, MO not seen, NY not seen, RB, SP not seen, U not seen). Figure 1.

Haec species Peritassae laevigatae (Hoffmannsegg ex Link) A. C. Smith foliis et inflorescentia structura affinis, sed inflorescentia puberula, antheris globosis et stigmate 3lobato differt. $\mathrm{Ab}$ omnibus speciebus sympatricis Tonteleae disco parietum ovarii libero et thecis in antherarum dehiscentia non confluentibus differt.

Liana, branches terete, new branches sparsely puberulous, older glabrescent, fissured. Leaves opposite to subopposite; stipules not seen, caducous; petioles 1.6-2 cm, canaliculate, glabrous; blades $(15.4-) 16.2-18.6(-19.8) \times 6.5-6.8(-8.7) \mathrm{cm}$, elliptic, the base cuneate, the apex acute or acuminate, the margin entire and thickened, glabrous, chartaceous, drying brown on the adaxial side and light brown and minutely tuberculate on the abaxial side, or brown on both sides, the nerves drying cream on the abaxial side, venation brochidodromous, veins prominulous on both sides, secondary veins inconspicuous. Inflorescence paniculate, (4.5-)6.3-6.7 × (2.5-)6.5-8.5(-10.5) cm, 


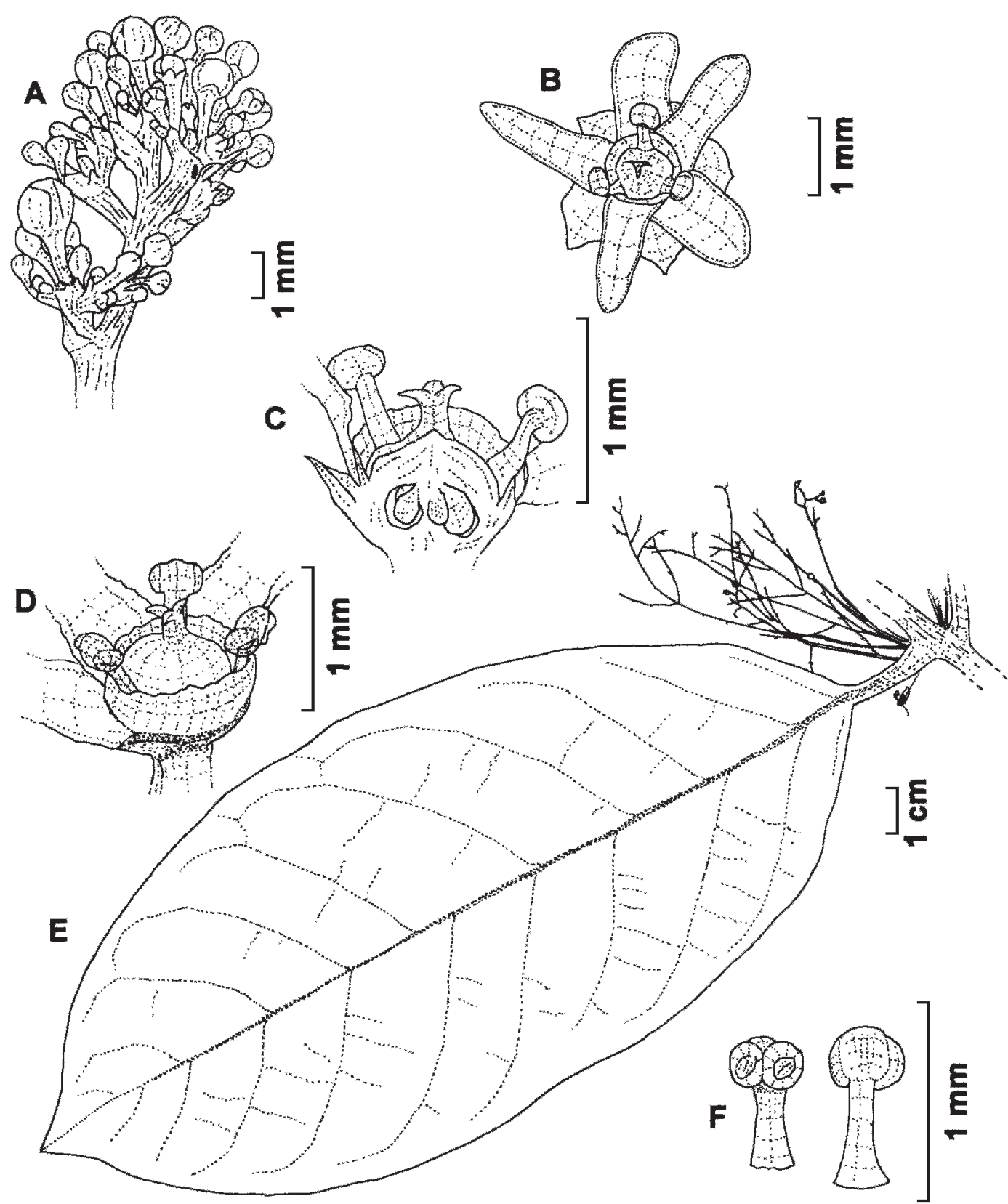

Figure 1. Peritassa manaoara Lombardi. - A. Apex of inflorescence branch. —B. Apical view of an open flower. -C. Lateral view of the middle section of an open flower showing disc, two stamens, and pistil. - D. Detail of an open flower showing disc, stamens, and pistil. —E. Branch with leaf and inflorescence. - F. Lateral and adaxial view of stamens. Drawings by the author: A from Bahia 222 (U); B-D, F from Assunção $726 A \&$ Souza (MG); E from the holotype Vicentini 789 \& Pereira (IAN).

with more than 400 flowers, axillary, sometimes at leafless nodes; peduncle obsolete, branches alternate or subopposite, terete, yellow-green, puberulous; bracts $0.5-0.7 \mathrm{~mm}$, triangular, the base puberulous, the margin fimbriate, proximal inflorescence dichotomies without bracts; pedicels (0.3)1.3-1.6 mm, terete, green, glabrous; bracteoles $0.3-0.4 \mathrm{~mm}$, triangular, the base puberulous, the margin fimbriate. Flowers ca. $3.4 \mathrm{~mm}$ wide at anthesis; sepals $5,0.8-0.9(-1.3) \times$ 0.8-1.2 mm, triangular, unequal, green, glabrous, \pm carnose, the margin fimbriate, minutely revolute; petals $5,(1.3-) 1.6-1.9 \times(0.7-) 0.8-0.9 \mathrm{~mm}$, elliptic, yel- 
lowish green or yellowish white, glabrous, \pm carnose, spreading at anthesis, transversally brown-maculate, the margin scarious; disc short-tubular, ca. $0.3 \mathrm{~mm}$ high, \pm carnose, free from reproductive parts, the margin minutely erose; stamens $3,0.37-0.64 \mathrm{~mm}$, in open flower slightly reflexed, the filaments flattened, the connective adaxially thickened, rounded at apex, slightly surpassing the thecae, the anthers 0.25-0.29 $\times \quad 0.36-0.43 \mathrm{~mm}$, gray, globose, basifixed, dehiscence extrorse by minute oblique slits; pistil $0.65 \times$ $0.55 \mathrm{~mm}$, ovary sub-spheroid, 3-locular, with 2 apical ovules in each locule, style ca. $0.32 \mathrm{~mm}$ after anthesis, central, terete, stigmas 3-lobed, ca. $0.18 \mathrm{~mm}$ diam. after anthesis, lobes ca. $0.1 \mathrm{~mm}$ after anthesis, entire, acute, appressed in bud. Mature drupes not seen, immature $2 \times 1.8 \mathrm{~cm}$, globose, pruinose; seeds not seen.

Phenology. Collected with flower buds in October and open flowers in November and December; collected with young fruits in March.

Distribution and habitat. Peritassa manaoara has been found in the rainforests around Manaus, capital city of the State of Amazonas, Brazil, and was also collected once in the Alto Rio Negro region, close to the Colombia-Brazil border.

In the Manaus region, where the Rio Negro converges with the Rio Solimões to form the Amazon River, several types of forests exist on flooded or not flooded areas in addition to forested to open shrubby formations on white sandy soils; the altitude ranges between 16 and $130 \mathrm{~m}$ (Nelson \& Herrera-MacBryde, 1997). Two collections of this new species were made inside the Adolpho Ducke Forest Reserve, a governmental research station managed by the Instituto Nacional de Pesquisas da Amazônia (INPA), which harbors ca. 2200 vascular plant species (Ribeiro et al., 1999) and includes forest on gentle slopes, Amazonian caatinga forest (campinarana), and black-water flood forest (igapó), with little human alterations, although it is in the process of being enclosed by the expanding urban area of Manaus (Ribeiro et al., 1999).

Conservation status. The occurrence inside the Adolpho Ducke Forest Reserve guarantees the preservation of this species in the near future, but the population status and the conservation perspectives outside the Forest Reserve are unknown, and Peritassa manaoara is classified as Data Deficient (DD) by the IUCN Conservation Status categories.

Etymology. The specific epithet of this species refers to Manaus city, capital of the State of Amazonas, in northern Brazil; the city Manaus was named for the Manu tribe, Aruake stem, that used to live there.

Although this new species resembles Peritassa laevigata through its leaves and general inflorescence pattern, it can be immediately distinguished by the presence of indument, anther shape (globoid vs. triangular), connective apex (rounded vs. apiculate), and 3-lobed stigma (vs. punctiform, unlobed stigma).

Close examination of the stamens with nonconfluent thecae and of the free nectariferous disc prevents any possible misidentification of this new species with the Tontelea species to which the presence of a lobed stigma could lead. The genus Tontelea distinguishes itself from Peritassa through the slits in the anther dehiscence (confluent on Tontelea vs. non-confluent on Peritassa) and the nectariferous disc adnation to the ovary wall (adnate on all 3-lobed stigma Tontelea species vs. free on all Peritassa species). Tontelea species also have relatively large oblong anthers $(0.2-0.4 \times 0.3-0.6(-0.8)$ $\mathrm{mm})$ with clearly transverse dehiscence slits and, as in the newly described species, 3-lobed stigmas; the exceptions are the aberrant species T. cylindrocarpa (A. C. Smith) A. C. Smith, T. myrsinoides A. C. Smith, and T. nectandrifolia (A. C. Smith) A. C. Smith, which have relatively smaller anthers $(0.1-0.3 \times 0.2-0.3$ $(-0.5) \mathrm{mm})$ and unlobed stigmas.

While the generic placement of the three divergent Tontelea species is still to be studied, the placement of Peritassa manaoara in the present genus follows the generic characteristics as defined in the monograph by Smith (1940).

Peritassa manaoara was cited as Tontelea fluminensis (Peyritsch) A. C. Smith in Ribeiro et al. (1999: 473 ), presenting a small color image of the flowers of this species on the lower left corner of the page.

Paratypes. BRAZIL. Amazonas: Res. Flor. Ducke, Manaus-Itacoatiara, km 26, próximo à torre, 27 Nov. 1997, P. A. C. L. Assunção $726 A$ \& M. A. D. Souza (MBM, MG); Manaus, estr. Itaquatiara, 30 Nov. 1962, A. G. Andrade 1378 \& M. Emmerich $1362(\mathrm{R})$; Manacapuru, margem do lago grande, 9 Oct. 1976, T. R. Bahia 222 (MG, U, UB); environs de Manaos, 1906, M. Labroy s.n. (P); margem da Estr. Perimetr. Norte [sic], Rio Negro, Uaupés, 4 Mar. 1975, B. G. S. Ribeiro 830 (IAN).

Acknowledgments. The author thanks T. S. Filgueiras for the Latin diagnosis, Mark P. Simmons for corrections in the manuscript, the Conselho Nacional de Desenvolvimento Científico e Tecnológico (CNPq) for the research fellowship grant (number 300220/ 2003-0), and the Fundação de Amparo à Pesquisa do Estado de São Paulo (FAPESP) for financial support (number 2005/00437-3). I also thank the curators of 
the following herbaria for their specimen loans: IAN, MBM, MG, P, R, RB, U, and UB.

\section{Literature Cited}

Hallé, N. 1990. Célastracées (Hippocrateoidées). Pp. 1-247 in B. Satabie \& P. Morat (editors), Flore du Cameroun 32. Ministère de l'Enseignement Supérieur de l'Informatique et de la Recherche Scientifique, Yaoundé.

Lombardi, J. A. 2004. Three new species of Celastraceae (Hippocrateoideae) from southeastern Brazil, and a new combination in Peritassa. Novon 14: 315-321.

\& L. G. Temponi. 1999. A new species of Peritassa Miers (Hippocrateaceae) from southern Brazil, and notes on two confused species. Novon 9: 221-226.

Mennega, A. M. W. 1997. Wood anatomy of the Hippocrateoideae (Celastraceae). I. A. W. A. J. 18: 331-368.

Miers, J. 1872. On the Hippocrateaceae of South America. Trans. Linn. Soc. London 28: 319-432.
Nelson, B. W. \& O. Herrera-MacBryde. 1997. Manaus region. Brazil. Pp. 325-332 in S. D. Davis, V. H. Heywood, O. Herrera-MacBryde, J. Villa-Lobos \& A. C. Hamilton (editors), Centres of Plant Diversity. A Guide and Strategy for Their Conservation, Vol. 3, the Americas. The World Wide Fund for Nature (WWF) and IUCN-The World Conservation Union, Cambridge.

Peyritisch, J. 1878. Hippocrateaceae. Pp. 125-164 in C. F. P. Martius \& A. G. Eichler (editors), Flora brasiliensis 11(1). Frid. Fleischer, Lipsiae.

Ribeiro, J. E. L. S., M. J. G. Hopkins, A. Vicentini, C. A. Sothers, M. A. S. Costa, J. M. Brito, M. A. D. Souza, L. H. P. Martins, L. G. Lohmann, P. P. C. L. Assunção, E. C. Pereira, C. F. Silva, M. R. Mesquita \& L. C. Procópio. 1999. Flora da Reserva Ducke: Guia de identificação das plantas vasculares de uma floresta de terra-firme na Amazônia Central. Instituto Nacional de Pesquisas da Amazônia, Manaus.

Smith, A. C. 1940. The American species of Hippocrateaceae. Brittonia 3: 341-555. 